Modern Asian Studies 52, 4 (2018) pp. 1420-1456. (C) Cambridge University Press 2018. This is an Open Access article, distributed under the terms of the Creative Commons Attribution licence (http://creativecommons.org/licenses/by/4.o/), which permits unrestricted re-use, distribution, and reproduction in any medium, provided the original work is properly cited.

doi:10.1017/Soo26749X1700049X First published online 27 March 2018

\title{
Continuity in Mind: Imagination and migration in India and the Gulf*
}

THOMAS CHAMBERS

\author{
Faculty of Humanities and Social Sciences, Oxford Brookes University, \\ Oxford, United Kingdom \\ Email:tchambers@brookes.ac.uk
}

\begin{abstract}
In the context of migration between Uttar Pradesh, other areas of India, and the Gulf, this article explores the role of the imagination in shaping subjective experiences of male Muslim migrants from a woodworking industry in the North Indian city of Saharanpur. Through attending to the dreams, aspirations, and hopes of labour migrants, the article argues that bridging the material and the imagined is critical to understanding not just patterns of migration, but also the subjective experiences of migrants themselves. Through a descriptive ethnographic account, involving journeys with woodworkers over one and a half years, the article explores the ways in which migration, its effects, and connections are shaped by the imagination, yet are also simultaneously active in shaping the imagination - a process that is self-perpetuating. Emerging from this, the article gives attention to continuity at the material, personal, and more emotive levels. This runs counter to research that situates migration as rupturing or change-driving within both the social and the subjective. These continuities play out in complex ways, providing comfort and familiarity, but also enabling the imaginations of migrants to be subverted, co-opted, influenced, and structured to meet the demands of labour markets both domestically and abroad.
\end{abstract}

* This research was funded through ESRG Doctoral Grant (ES/Igoo934/1), held at the University of Sussex. I would like to sincerely thank my doctoral supervisors, Filippo Osella and Geert De Neve, for their boundless support both during thesis preparation and since. I would also like to thank my many colleagues at the University of Sussex and dear friends in Saharanpur who opened up their lives, homes, and workplaces to me during fieldwork. 


\section{Introduction}

This article explores labour migration between Uttar Pradesh (India) and the Gulf. The article engages with both internal and international migration, working across and problematizing this dichotomy. The primary contribution is developed through an exploration of the imaginations of migrants and the ways in which this intersects with expectations and experiences of migration. Through attending to the dreams, aspirations, and hopes of labour migrants, the article argues that bridging the material and the imagined is critical to understanding not just patterns of migration, but also the subjective experiences of migrants themselves. Taking part in internal migration may provide connections beyond the domestic, but it is also a key factor in shaping ideas about, and experiences of, migration further afield. By working across the imagined and the material, as well as international and domestic migration, the ethnographic description illuminates the importance of attending to the forms of continuity experienced by migrants that create a sense of familiarity and comfort as opposed to the rupture, change, or disjuncture that often features more strongly in work on various forms of migration. Continuity is essential, as it not only eases the transition to becoming a migrant, but also creates degrees of passivity and compliance towards the conditions that migrants encounter in workplaces within India and in the Gulf. Labour migrants themselves articulate both continuity and change in their narratives when discussing migration. However, the article focuses not only on migrants' narratives, but also on more sensual and emotive aspects that are critical in understanding the shaping of the imaginations of labour migrants. As such, the article is based on one and a half years of ethnographic fieldwork that involved travelling, living, and labouring with migrants in a Muslim woodworking community from the North Indian city of Saharanpur, as well as the gathering of interview data and life stories, often from friends and informants with whom relationships were cultivated over substantial periods of time.

Through an engagement with the imaginations of migrants, I situate migration as an ongoing process of 'envisioning and becoming' ${ }^{1}$ a process rather than a relationship between imagined possibilities

${ }^{1}$ C. Freeman, Entrepreneurial Selves: Neoliberal Respectability and the Making of a Caribbean Middle Class, Duke University Press, Durham, NC, 2014. 
and achieved outcomes. ${ }^{2}$ The article uncovers a more subjective account of labour migration between India and the Gulf. I utilize 'the imagination' as an umbrella term encompassing a range of more affective considerations but also attend to culturally specific understandings of the imagination. In addition, as an affective terrain, the imaginations of potential and current migrants as well as those of returnees are shaped not just through engagement with the material, but also within a landscape of multiple and at times competing visions of what should be imagined and what should be desired. As such, the imagination is struggled over, and forms a terrain where influence may be sought by states, media, religious organizations, employers, and others. Such appeals may be direct but often are subtler and play as much to familiarity and continuity as they do to dreams of individual or collective transformation.

The article is arranged into five sections. The first draws on current literature dealing with migration and the imagination. This material is primarily focused on transformative or rupturing aspects of migration, leaving continuity somewhat unattended to. The second section moves toward a more ethnographic engagement by placing migration from the city within a historical context that draws on the experiences of migrants themselves and the history of the community. The third section provides a detailed account of time spent working and living with migrants from the city in other parts of India. This section draws attention to the importance of embodying migration, to begin comprehending more affective aspects that are often not articulated by migrants, but can only be interpreted through shared experience. The fourth section returns to the historical context to understand the ways in which the Gulf is imagined. It also utilizes material gathered in Saharanpur itself to explore the ways in which potential migrants view the Gulf and how migrants may be viewed in the imaginations of others. The final section returns to an experiential account of sharing elements of everyday life with migrants in the Gulf. Here, attention is paid to both emotive and material aspects of life in the Gulf and the ways in which continuities persist from experiences of home and prior engagements with migration. This, the section argues, is critical to understanding how the Gulf is imagined and experienced as well as the potentialities and limitations for imagining transformative forms of change or resistance.

\footnotetext{
${ }^{2}$ Freeman deals with entrepreneurialism but the 'process' nature of self-making is also relevant to migration.
} 


\section{Imagining the imaginable}

A growing body of work explores the role of the imagination in migration. Whilst not dismissing 'the economic', these studies discuss how imaginaries of migrants form an important 'non-economic' consideration. ${ }^{3}$ For Saharanpur's craft workers, movement, migration, and connectedness are a part of everyday life. Despite labour migration from the city only beginning in earnest in the early 1980 , following a downturn in the wood industry, craft workers now access networks that extend to every corner of India and to the Gulf. The rapid formation of these networks and the ease with which craft workers transitioned into being a migrant community create a different image of migration to accounts where it is seen as a 'disjuncture' ${ }^{4}$ or 'rupture' ${ }^{5}$ It was the preexistence of the possibility of migration in the imaginations of those in the city that smoothed this transition. As an elderly craft worker framed it: 'we were ready to leave for work; we are craft workers and we often moved workshops and went to nearby towns. So to go further was not such a big thing ... we could imagine it already. ${ }^{6}$

Imaginaries were shaped through a variety of factors including prior histories of migration held in the collective memory, a religiosity which created a sense of connection to other places, the importance

${ }^{3}$ G. E. Marcus, 'Multi-sited ethnography: notes and queries' in Multi-sited Ethnography: Theory, Praxis and Locality in Contemporary Research, M. A. Falzon (ed.), Ashgate, Farnham, 2009, pp. 181-96; R. Radhakrishnan, 'The Gulf in the imagination: migration, Malayalam cinema and regional identity', Contributions to Indian Sociology, vol. 43, no. 2, May 2009, pp. 21 7-45; A. Smith, "If I have no money for travel, I have no need": migration and imagination', European Journal of Cultural Studies, vol. 9, no. 1, February 2006, pp. 47-62; A. Coles and K. Walsh, 'From "trucial state" to "postcolonial" city? The imaginative geographies of British expatriates in Dubai', Journal of Ethnic and Migration Studies, vol. 36, no. 8, September 2010, pp. 1317-33; K. Halfacree, 'A utopian imagination in migration's terra incognita? Acknowledging the non-economic worlds of migration decision-making', Population, Space and Place, vol. 10, no. 3, May 2004, pp. 239-53.

${ }^{4}$ S. B. Cwerner, 'The times of migration', Journal of Ethnic and Migration Studies, vol. 27, no. 1, January 2001, pp. 7-36; M. B. Mills, 'Contesting the margins of modernity: women, migration, and consumption in Thailand', American Ethnologist, vol. 24, no. 1, February 1997, pp. 37-61; A. Ong, 'The production of possession: spirits and the multinational corporation in Malaysia', American Ethnologist, vol. 15, no. 1, February 1988, pp. $28-42$.

${ }^{5}$ M. Griffiths, A. Rogers, and B. Anderson, Migration, Time and Temporalities: Review and Prospect, COMPAS Research Resources Paper, Centre on Migration, Policy and Society, Oxford, 2013, https:/www.compas.ox.ac.uk/media/RR-2013-Migration_ Time_Temporalities.pdf, [originally accessed 5 March 2016, no longer available].

${ }^{6}$ Mohammad Mehboob, an elderly wood worker, 2011. 
given to holders of knowledge of localities within India or beyond, and ideas of personal change or transformation. Yet the imagination is not only a part of conceiving migration. Imaginaries are shaped, changed, and even transformed by migration itself. Imagining departure, going elsewhere, returning, and imagining again form a constant process in which the self is crafted and re-crafted and through which more collective visions are forged and re-forged.

Although I foreground the imagination, I do not dismiss structural considerations. The materiality of migration is itself intimately involved in the shaping of migrant imaginaries. As Tim Ingold ${ }^{7}$ suggests, the formation of a dichotomy segmenting the imagination from the real renders the imagination as little more than a floating 'mirage above the road we tread in our material life'. Ingold evocatively illustrates a blurring of the real and the imagined. The imagination, he argues, is active in carving out 'paths' or 'ways'. Imagining is not an act of absent-minded pondering, but instead directs engagements with the material and is itself shaped through such engagements. Ingold is primarily concerned with production. However, migration, its effects, and connections are also shaped by the imagination and simultaneously active in shaping the imagination-a process that is self-perpetuating. This is not to suggest an organic or independent progression free of constraints, structural conditions, and regulatory frames. Rather, there are possibilities for migration to cultivate new subjectivities or forms of consciousness that may offer challenges to normalized hierarchies, structures, or inequalities. ${ }^{9}$ However, there are also various ways in which the imaginations of migrants can be subverted, co-opted, influenced, and structured to meet the demands of labour markets both domestically and abroad.

Amira Mittermaier ${ }^{10}$ has recently argued that ethnographic explorations of the imagination 'matter in the sense of having significance in people's lives and, more literally, in the sense of having

${ }^{7}$ T. Ingold, 'Dreaming of dragons: on the imagination of real life', Journal of the Royal Anthropological Institute, vol. 19, no. 4, December 2013, pp. 734-52.

${ }^{8}$ Ibid., p. 735 .

${ }^{9}$ See, for example, E. Simpson, 'Migration and Islamic reform in a port town of western India', Contributions to Indian Sociology, vol. 37, no. 1-, February 2003, pp. 83-108; K. Gardner, 'Lives in motion: the life-course, movement and migration in Bangladesh', Journal of South Asian Development, vol. 4, no. 2, July 2009, pp. 229-51.

${ }^{10}$ A. Mittermaier, Dreams that Matter: Egyptian Landscapes of the Imagination, University of California Press, Berkeley, CA, 2010. 
an impact on the visible, material world'. ${ }^{11}$ Mittermaier deals with the Egyptian context and not specifically with migration, yet there are considerations in her engagement with the imagination that intersect in important ways with the imaginaries under question in this article. Mittermaier draws attention to the intersection of dreams and imaginaries with Islamic influences as well as the specifics of the Egyptian cultural context. She reminds us that the imagination, or at least the ways in which the imagination is conceived of, and the role it is seen to play, is both culturally diverse and non-static. Thus, she tells of an informant complaining that the government used to steal money but now they also take people's dreams. For the marginalized Muslim population in the north of India, imaginaries are also bound up in a structural environment that sidelines and spatially confines Muslim communities-a process that can be seen as closing down the imaginable. Yet connections and horizons, as well as limitations, are very much a part of the aspirations and dreams ${ }^{12}$ of those in the city's mohallas (neighbourhoods). As migration, both domestic and international, becomes increasingly commonplace, so these horizons shift as new forms of imagining are established.

As with Mittermaier's engagements in Egypt, Islam too plays a role in shaping the way in which the imagination itself is conceived. Mittermaier situates Insha Allah (God willing), a phrase common amongst all Muslims, as 'continually reminding believers of their embeddedness in larger orders'. ${ }^{13}$ This sense is rearticulated within the Urdu used in Saharanpur-in particular, the notion of kismet (destiny/fate) that situates the actual outcome of imagined futures as lying not within the agency of the individual, but in the hands of Allah. Yet there is also space in the vocabulary deployed by labour migrants and others from the city (and beyond) that allows a more subjective understanding of the imagination. Nasriya ('standpoint' or the position from which one sees the world) acknowledges not only different subjectivities, but also the idea that the imagination is fluid as one's relationship with the material shifts over time. The nasriya of someone who has never migrated may therefore be discussed as being

${ }^{11}$ Ibid., p. 2.

${ }^{12}$ Jamie Cross has illustrated the importance of attending to such aspects, in the Indian context, when considering not only change or resistance, but also forms of passivity, acceptance, and compliance with capitalist forms of development. See J. Cross, Dream Zones: Anticipating Capitalism and Development in India, Pluto Press, London, 2010.

${ }^{13}$ Mittermaier, Dreams that Matter, p. 3. 
more limited than that of the returnee migrant who has broadened his ${ }^{14}$ horizons and gleaned knowledge of other places.

This draws attention to cultural specificities and asks that we consider not only the ways in which cultural context shapes what is imagined (or not imagined), but also the ways in which the imagination itself may be defined or conceived of within a given context. It also intersects with a broader body of work on migration and the imagination that attends to various facets of the imaginations of migrants. A historical imagination, ${ }^{15}$ for example, considers how histories of mobility and pre-existing connections (either travelled or imagined) contribute to contemporary movement. ${ }^{16}$ Here, connections formed through colonial activity, circuits of trade, conflict, or alliances live on in cultural and social practice. ${ }^{17}$ Work on the 'religious imagination' in the context of migration emphasizes the role of religious identity, networks, pilgrimage, and travel in shaping the imagination. This involves both physical and temporal movement such as a journey of the soul or a shift to a purer and more pious form of being. ${ }^{18}$ Others have attended to the forms of 'spatial knowledge'

${ }^{14}$ It is important to acknowledge the relative absence of women in this article. In part, this is a consequence of the authors own positionality; it also reflects the fact that migration from Saharanpur's wood mohallas is almost entirely a male pursuit. This is not to say that women were not involved. Women are often a part of decision-making processes and are very much active in the sculpting of collective imaginations. However, the article's focus on the ways in which engaging in the actual act of migration affects subjectivities and collective imaginaries draws the focus, in a context were work and particularly migration are highly gendered, onto male life-worlds. Whilst other areas of fieldwork specifically explored women's experiences (see, for example, T. Chambers and A. Ansari, 'Blurring the boundaries: from home to factory to "home", Journal of South Asia Development, in progress), the ethnographic engagement with migration was one that involved almost constant emersion in all-male spaces of work and sociality. Here, then, there is a limitation to this ethnography that must be acknowledged, although comparative engagements with other ethnographic material exploring various experiences of migrant women illustrate that the arguments are by no means singular to male migrants.

${ }^{15}$ This is not to say these are the only categories, but they are the most commonly deployed in the literature.

${ }^{16} \mathrm{~J}$. Comaroff and J. Comaroff, Ethnography and the Historical Imagination, Westview Press, Boulder, 1992; R. Shaw, Memories of the Slave Trade: Ritual and the Historical Imagination in Sierra Leone, University of Chicago Press, Chicago, 2002.

${ }^{17}$ Thus, Shaw, for example, details how the ritual practices and images of the Temne in Sierra Leone have been shaped through historical engagement with the Atlantic slave trade, the memory of which has become incorporated into cultural and social practice.

${ }^{18}$ D. F. Eickelman and J. P. Piscatori, 'Preface' in Muslim Travellers: Pilgrimage, Migration, and the Religious Imagination, D. F. Eickelman and J. P. Piscatori (eds), 
individuals, groups, or communities may possess that allows images of other places to form ${ }^{19}$-images that may be outward-looking ${ }^{20}$ or enclaving. ${ }^{21}$ Here, a 'geographical imagination' may embody power or status where the holders of geographical knowledge are revered and thus cultivate the imaginations of others seeking similar prestige. ${ }^{22}$ Within the imaginaries of potential migrants, the 'geographical imagination' can become 'a projection of migrant's conceptions of place ... embedded in the minds of those who wish to leave in search of their "dream". ${ }^{23}$

These approaches all seek to understand how the imaginations of migrants are shaped and thus how this impacts on experiences of migration. Others, however, have focused on the ways in which migration itself affects the imagination and fundamentally changes what may be imaginable. Contributions dealing with the 'social imagination' envisage migration as holding potential to drive new forms of resistance or social transformation whilst simultaneously being sought to be controlled by states and others through media, spectacle, and drama. ${ }^{24}$ Here, migration invokes revolutionary potential, although in a post-structural rather than a vanguard context. ${ }^{25}$ In terms of migration, it explores potentialities within increasingly de-territorialized or trans-global imaginariesimaginaries that hold emancipatory possibilities where imagined worlds' may enable subversions and challenges to established hierarchies and relations of power. Thus, increasing mobility creates

California University Press, Berkeley, CA, 1990; J. W. Fernandez, Bwiti: An Ethnography of the Religious Imagination in Africa, Princeton University Press, Princeton, 1982; M. Johnson and P. Werbner, 'Diasporic encounters, sacred journeys: ritual, normativity and the religious imagination among international Asian migrant women', Asia Pacific Journal of Anthropology, vol. 1 1, no. 3-4, 2010, pp. $205^{-18}$.

${ }^{19}$ Marcus, 'Multi-sited ethnography'.

${ }^{20}$ D. Massey, 'A global sense of place', in Space, Place and Gender, D. Massey (ed.), Polity Press, Cambridge, 1994.

${ }^{21}$ P. Jackson, 'Constructions of "whiteness" in the geographical imagination', Area, vol. 3o, no. 2, 1998, pp. 99-106.

${ }^{22} \mathrm{~S}$. Schulten, The Geographical Imagination in America, I880-1950, University of Chicago Press, Chicago, 2001.

${ }^{23}$ Marcus, 'Multi-sited ethnography'.

${ }^{24}$ A. Appadurai, Modernity at Large: Cultural Dimensions of Globalization, University of Minnesota Press, Minneapolis, MN, 1996; C. Calhoun, 'Nationalism and the contradictions of modernity', Berkeley Journal of Sociology, vol. 42, January 1997, pp. 1-30; D. P. Gaonkar, 'Toward new imaginaries: an introduction', Public Culture, vol. 14, no. 1, Winter 2002, pp. 1-19; C. Taylor, 'Two theories of modernity', Public Culture, vol. 11 , no. 1, January 1995, pp. 153-74.

${ }^{25}$ Gaonkar, 'Toward new imaginaries'. 
new forms of instability capable of freeing the imagination from preexisting social controls. ${ }^{26}$

Within much of this work, migration is seen as fostering new horizons within the imaginations of those involved, leading to the emergence of new subjectivities that situate migrants, within Marxist-orientated perspectives, as vanguards of change ${ }^{27}$ or, within pluralist and some post-structural approaches, as the embodiment of cosmopolitanism. ${ }^{28}$ Such cosmopolitan ideals are identified as enabling increased cultural versatility, a sense of the 'spatial diffusion of ideas', and 'a geographical imagination secured by notions of discrete, self-evident places and subjects awaiting transformation through the cultivation of a universal ethos' ${ }^{29}$ Whilst horizons may broaden, this is not to confuse the cosmopolitan nature of craft workers in Saharanpur with increased social mobility. Subaltern cosmopolitanisms play out at various levels of hardship and affluence. As Carol Breckenridge et al. argue: 'Cosmopolitans today are often the victims of modernity, failed by capitalism's upward mobility, and bereft of those comforts and customs of national belonging. Refugees, peoples of diaspora and migrants represent the spirit of cosmopolitan community. ${ }^{30}$ However, not all of those who traverse borders or engage in travel fit the cosmopolitan mould. ${ }^{31}$ Thus, in his discussion of 'demotic' (of the people) cosmopolitanism in an Indian steal plant, Jonathon Parry ${ }^{32}$ argues that class positioning is critical in shaping the imaginative horizons of workers [and that] regular company workers in the public sector steel plant are most cosmopolitan [whilst] workers in private sector factories are more likely to be encapsulated by kinship, caste and regional community. ${ }^{33}$

It is, then, important to consider the ways in which the imagination can act to limit what can and cannot be conceived, creating

${ }^{26}$ Appadurai, Modernity at Large.

${ }^{27}$ A. De Haan and B. Rogaly, 'Introduction: migrant workers and their role in rural change', Journal of Development Studies, vol. 38, no. 5, June 2002, pp. 1-14.

${ }^{28} \mathrm{~V}$. Gidwani and K. Sivaramakrishnan, 'Circular migration and rural cosmopolitanism in India', Contributions to Indian Sociology, vol. 37, no. 1-2, February 2003, pp. 339-67.

${ }^{29}$ Ibid., p. 343, emphasis added.

${ }^{30}$ C.A. Breckenridge, Cosmopolitanism: $X A-G B$, Duke University Press, Durham, 2002 , p. 6.

${ }^{31}$ P. Werbner, Anthropology and the New Cosmopolitanism: Rooted, Feminist and Vernacular Perspectives, Berg, Oxford, 2008.

${ }^{32} \mathrm{~J}$. Parry, 'Cosmopolitan values in a central Indian steel town', in Werbner, Anthropology and the New Cosmopolitanism, pp. 325-43.

${ }^{33}$ Ibid., p. 327 , emphasis in original. 
acceptance, compliance, and even docility. As David Harvey ${ }^{34}$ reminds us, cosmopolitan connections are also fundamental to globalized production and consumption. A 'cosmopolitan imagination' may echo ideologies of globalization and act in the stratification of labour markets. ${ }^{35}$ However, simply identifying it within the imaginations of a community or labour force does not automatically facilitate the production of 'progressive political agendas' ${ }^{36}$ In the context of migration, for example, Mary Beth Mills ${ }^{37}$ argues that the 'potential exists for the production of new meanings and practices in the resulting disjuncture between dominant meanings and lived experience, and between imagined possibilities and limited opportunities' ${ }^{38}$ However, as Mills ${ }^{39}$ points out, migrants' encounters with, for example, capitalist wage labour may not necessarily lead to the proletarian resistance imagined in classical models. Similarly, Aiwya Ong ${ }^{40}$ focuses on the rupturing nature of rural female Malaysian migrants whose imaginings of life in the city are not met by the realities of industrial production. Here, new forms of resistance are conjured as women become possessed by spirits in order to express the distress they feel at the conditions they find themselves in. Whilst indirect forms of resistance may emerge, this is more connected to the shock of a dramatic change in life than with a sense of consciously challenging injustice or exploitation.

Throughout this material, whether focused on enabling or exploitative aspects of migration, the emphasis is on change, transformation, rupture, or disjuncture. Migrations act to create shifts in the imaginations of those involved in the process-the self becomes transformed, the social reconfigured, the hierarchy challenged, or the body and person shocked. Yet the imagination is not only shaped through change or necessarily creating of transformative processes, nor is it always about breaking out (imaginatively or materially) from a relatively enclaved context. Throughout my time in Saharanpur,

${ }^{34}$ D. Harvey, 'Cosmopolitanism and the banality of geographical evils', Public Culture, vol. 12, no. 2, Spring 2000, pp. 529-64.

${ }^{35}$ S. Castles, 'Cosmopolitanism and freedom? Lessons of the global economic crisis', Ethnic and Racial Studies, vol. 35, no. 11, 201 2, pp. 1843-52.

${ }^{36}$ Gidwani and Sivaramakrishnan, 'Circular migration', p. 362.

${ }^{37}$ Mills, 'Contesting the margins', pp. 37-61.

${ }^{38}$ Ibid., p. 41, emphasis added.

${ }^{39}$ Citing A. Ong, 'The gender and labor politics of postmodernity', Annual Review of Anthropology, vol. 20, no. 1, October 1991, pp. 279-309.

${ }^{40} \mathrm{Ong}$, 'The production of possession', pp. 28-42. 
the most emotive aspect of fieldwork was bound up in male sociality, its associated expectations, intimacies, comfort, and obligation. The wood gullies are, within the public sphere at least, a male space. In this crowded spatial context, sociality regularly overlaps with business and production. Young men and boys entering the industry do so in a context bound up in friendships fostered through childhood and youth in the equally congested residential areas that wind off the main spaces of production. Banter, warmth, arguments, fallings-out, reconciliations, and intimacy are a constant background to the emotive context of the everyday. This terrain is not limited to Saharanpur alone, but is very much a part of migrant life in other areas of the country. Journeys are usually made in small groups with work and life on the road playing out in necessarily intimate environments. Beyond the domestic context, too, the labour camps of the Gulf hold much that is familiar. Dormitory rooms are usually occupied by men of similar social backgrounds and the everyday intimacy and sociality of life interplay with the imaginations of migrants to instil a sense of familiarity and comfort rather than rupture or disjuncture.

There are other continuities also. In the context of a developing culture of migration in Hyderabad, Syed $\mathrm{Ali}^{41}$ describes the ways in which migrants may be seen as heroic on return and that migration itself has triggered forms of social change, but also points out that migrants' preferences towards, for example, Saudi as a destination is tied up with degrees of familiarity with areas of Jeddah strongly resembling Hyderabad. He also argues that migration has become so normalized in the city, particularly within the Muslim population, that the counter-cultural act is no longer to migrate, but to choose not to migrate. Saharanpur has also seen the emergence of a 'culture of migration' that has normalized domestic migration ${ }^{42}$ and, with migration to the Gulf continuing to grow, the degrees to which a returnee may be seen as exceptional is also dissipating. ${ }^{43}$ Yet, as echoed in the words of the elderly woodworker Mohammad

${ }^{41} \mathrm{~S}$. Ali, "Go west young man": the culture of migration among Muslims in Hyderabad, India', Journal of Ethnic and Migration Studies, vol. 33, no. 1, January 2007, pp. $37-5^{8}$.

${ }^{42}$ Surveys conducted during fieldwork revealed that almost 60 per cent of Saharanpur's male woodworkers had migrated within India at least once.

${ }^{43}$ Uttar Pradesh, the state where Saharanpur is located, registered 191,341 emigrants to the Gulf in 2012-a massive increase from 27,428 in 2004. Thus, total migrant numbers now exceed Kerala, Andhra Pradesh, and Tamil Nadu, which previously dominated. 
Mehboob, ${ }^{44}$ this sense of normalization around migration was not limited to the period post the emergence of the current flows beginning in the 1980 s, but also cemented in older memories embedded within the collective imaginary of the city's Muslim population. Before returning to the descriptive material that evokes more emotive concerns unpinning the imaginaries of migrants, I turn to the historical context - a context that is also active in the imaginations of potential, current, and returning migrants.

\section{A brief history: the 'rupture' of partition and the 'continuity' of artisan mobility}

Migration from Saharanpur began in earnest from the early 1980 . The woodworking industry had been growing, sucking in labour. Eventually, new legislation ${ }^{45}$ aimed at closing saw mills and increased competition from elsewhere led to a decline. Economic factors, then, were important as workers began to seek work beyond the city. Yet the stories of returnees, the ideas and styles they brought back, also shaped the imaginations of others. Early migrants obtained status and social capital upon return, with their newfound 'geographical knowledge' regularly sought by relatives, neighbours, and friends. Rizwan, ${ }^{46} \mathrm{a}$ close friend of mine and woodcarver in his early forties, told of how his decision to first head out from Saharanpur was heavily influenced by a returning friend who brought stories of meeting movie heroes in Mumbai and a style reminiscent of Amitabh Bachchan. ${ }^{47}$ The friend's return contributed to Rizwan's own ability to envisage a journey and imagine its outcomes. The easy acceptance of migration, however, was not merely rooted in imagined dreams or an emerging migratory culture. Whilst forwarding a 'culture of migration' as the primary facet driving outward movement is useful, it ignores the unequal relations embedded in such processes and makes a pretence toward ideological neutrality that may shroud links between movements of labour and neoliberalism. ${ }^{48}$ It also posits migration as emerging within

\footnotetext{
${ }^{44}$ See the 'Introduction' section.

${ }^{45}$ This appears to have been the 1980 Forest (Conservation) Act.

${ }^{46}$ All names appearing in this article have been changed.

${ }^{47}$ Legendary Bollywood movie star.

${ }^{48}$ Halfacree, 'A utopian imagination'.
} 
a relatively a-historical context and gives little account of previously trodden pathways and histories of connection.

Work from elsewhere in India has explained this in terms of continuity where, although changing, migration exists as an ongoing feature of communities, dependent on complex imagined geographies and landscapes. ${ }^{49}$ For those in Saharanpur, the willingness to migrate can be located not just within emerging cultures, but also in experiences related to Muslim identity and the history of the wood industry. Not least in importance here is the dramatic change experienced in the city during partition. Saharanpur saw a large concentration of incoming Hindu and Sikh refugees. ${ }^{50}$ Whilst it is often suggested that those leaving for Pakistan were primarily middleclass Muslims, ${ }^{51}$ some accounts from the period also suggest that many artisans were amongst those departing. ${ }^{52}$ Jonathan Addleton, ${ }^{53}$ working on Pakistan, links easy acceptance of migration to the Gulf with the upheavals of partition that left a 'legacy of unsettlement', ensuring willingness to accept further movement. As with Addleton, the collective memory and 'communal imagination" ${ }^{\text {'4 }}$ of Saharanpur's Muslim population hold a migratory experience far more 'rupturing' than relocation for work.

Yet 'unsettlement' does not only reside within memories of partition. Craft industries have long required physical mobility. Weavers in Banaras, for example, originate from Samarkhand, Kashmir, and Persia, ${ }^{55}$ and Saharanpur's wood industry was likely established by migration from Kashmir after Mughal rule collapsed there in the mid-1 700 s. $^{56}$ The growth in migration from the $1980 \mathrm{~s}$ onwards is, then, less of an emergence than a re-emergence. The movement of populations, workers, and others in India is neither

${ }^{49}$ De Haan and Rogaly, 'Introduction'.

${ }^{50} \mathrm{Y}$. Khan, 'The arrival impact of partition refugees in Uttar Pradesh, 1947-52', Contemporary South Asia, vol. 12, no. 4, December 2003, pp. 51 1-22.

${ }^{51}$ A. Waheed, Muslim Artisans, Craftsmen and Traders: Issues in Entrepreneurship, Icon, New Delhi, 2006.

${ }^{52}$ Khan, 'The arrival impact'.

${ }^{53}$ J. S. Addleton, Undermining the Centre: The Gulf Migration and Pakistan, Oxford University Press, Karachi, 1992.

${ }^{54}$ Comaroff and Comaroff, Ethnography.

${ }^{55}$ N. Kumar, The Artisans of Banaras: Popular Culture and Identity, I880-1986, Princeton University Press, Princeton, 1988.

${ }^{56}$ O. Handa and M. Jain, Wood Handicraft: A Study of Its Origin and Development in Saharanpur, Indus, Delhi, 2000. 
new nor exceptional. ${ }^{57}$ Contrary to interpretations of immobility and stagnation, ${ }^{58}$ even in the pre-colonial period, political upheavals, conflict, patronage, and economic (re)structuring triggered relocation, eviction, and other migrations. ${ }^{59}$ Regarding craft workers specifically, Douglas Haynes and Tirthankar Roy ${ }^{60}$ suggest that 'weavers were always mobile, always willing to pick up from regions in decline and move to those showing signs of expansion. Mobility has always been a strategy for ensuring subsistence, surviving famine, improving economic livelihoods and, in some cases, resisting efforts to control weavers' labour'. ${ }^{61}$ For woodworkers, too, there has long been a sense of the mobile journeyman embedded within the identity of the labour force that persists even through periods of relative immobility. It is, then, within this broader historical context, much of which persists in the corners of the communal and individual imagination, that migration from the city needs to be understood.

This re-emerged mobility was also contained within persisting cultural traits such as an emphasis on the importance of gumnai (roaming) that pre-dated recent large-scale labour migration. For young men, such as Rizwan's eldest son, Abdul, migration acted as a rite of passage. This began in local neighbourhoods. The tightly packed gullies provided highly social spaces through which it was not possible to pass without being waylaid by friends or relatives. Rizwan encouraged Abdul to spend time outside the home, telling me that it was important to build networks. Rizwan regularly headed discussions, at household level, ${ }^{62}$ regarding sending Abdul further afield. Instrumental considerations were at play. However, Abdul's own view was one of excitement. Many of his friends had been out and he looked forward to time away working with pals and seeing other areas.

${ }^{57}$ K. Gardner and F. Osella, 'Migration, modernity and social transformation in South Asia: an overview', Contributions to Indian Sociology, vol. 37, no. 1-2, May 2003, pp. v-xxviii; De Haan and Rogaly, 'Introduction'.

${ }^{58}$ Such as W. H. Moreland, The Agrarian System of Moslem India: A Historical Essay with Appendices, Cambridge University Press, Cambridge, 1929.

${ }^{59}$ D. Haynes and T. Roy, 'Conceiving mobility: weavers' migrations in pre-colonial and colonial India', Indian Economic Social History Review, vol. 36, no. 1, March 1999, pp. 35-67; Kumar, The Artisans of Banaras; E. Vanina, Urban Crafts and Craftsmen in Medieval India (Thirteenth to Eighteenth Centuries), Mushiram Manoharlal, New Delhi, 2004.

${ }^{60}$ Haynes and Roy 'Conceiving mobility'.

${ }^{61}$ Ibid., p. 88.

${ }^{62}$ E. S. Massey, J. Arango, G. Hugo, A. Kouaouci, A. Pellegrino, and J. E. Taylor, The Ethnicity Reader: Nationalism, Multiculturalism and Migration, Blackwell, London, 1997. 
For many young men in Saharanpur, migration had become normalized to the degree that it represented a rite of passage into manhood. ${ }^{63}$ Indeed, evidence suggests that migration itself may speed the journey to maturity. ${ }^{64}$ Alessandro Monsutti, ${ }^{65}$ for example, describes journeys of young Afghan men migrating for work to Iran as 'conceived as a necessary stage in their existence, a rite of passage to adulthood and then a step towards manhood ${ }^{166}$ - a factor echoed in the imaginations of young men such as Abdul. Returnees gained prestige with peers but were also acknowledged within the family as having achieved a transition. Thus, after Abdul's first trip, Rizwan's language with his eldest son changed. A kindly but commanding tone was replaced by the more informal bhai (brother), denoting (or suggesting) a degree of egalitarianism in their relationship. For Monsutti, migration provides not just an avenue to manhood, but a means of broadening social networks beyond kin and family. For Saharanpur's craft workers, however, the broadening of networks was not just about facilitating migration or business, but was also critical to survival in a fundamentally precarious occupation. Migration had become defined as a liminal period through which manhood could be achieved, but the degrees of transition that were possible and imaginable had shifted with the normalization of migration. The boy could become a man but, unlike Rizwan's friend returning from Mumbai in the 1980 s, the returnee was no longer seen as the hero.

\section{Internal migration: dreaming with others}

On a Wednesday morning in August 2011 outside Saharanpur's railway station, following the Eid holiday, Faisal gathered with friends to travel to Udaipur in Rajasthan in search of work. Many had returned to Saharanpur from elsewhere prior to Eid. This, along with weddings

\footnotetext{
${ }^{63}$ Whilst it is possible to surmise that, for young men, migration may open a liminal period that provides a rite of passage (A. Van Gennep, The Rites of Passage, University of Chicago Press, Chicago, 196o [1909]), it should be noted that many older men are also engaged and that, for some, migration becomes a permanent state rather than a liminal period.

${ }^{64}$ F. Osella and C. Osella, Social Mobility in Kerala: Modernity and Identity in Conflict, Pluto, London, 2000.

${ }^{65}$ A. Monsutti, 'Migration as a rite of passage: young Afghans building masculinity and adulthood in Iran', Iranian Studies, vol. 40, no. 2, April 2007, pp. 167-85.

${ }^{66}$ Ibid., p. 169 .
} 
and other festivals, contributed to the circular nature of migration and offered an opportunity to exchange information. Their discussion focused on the delayed train. Usman, the least optimistic, suggested 'oh we should go in a few days ... there is still enough money to enjoy after Eid for some more time, let us leave now and go to the bazaar. We can go after Friday [the Muslim holiday]'. Eventually the decision was made and tickets returned. This ambivalence towards departure was commonplace and friends in the wood gullies would regularly call off trips at short notice. Likewise, departures themselves could be highly impulsive, with decisions to travel substantial distances across the country made at the drop of a hat. This was, then, no carefully planned strategy conceived and imagined over weeks or months, but a familiar process easily accepted and easily abandoned. Rizwan summed this up when recalling an earlier journey to Madras:

My friends took me for Madras. If you are my friend and you come at my home and I suggest some place to go like a garden, then you go. My friend came and suggested it to me so we went there. It is the tradition or link of Saharanpur's business that a friend who has been in some place advises us for the work there.

For Faisal, too, migration had never been a difficult undertaking. After taking Faisal back to his village, close to Saharanpur, we discussed his past journeys. Like Rizwan, Faisal had migrated often, first at the age of 14. As with Rizwan, Faisal's image of migration was shaped through dreams of adventure as well as economic considerations. As a young man, he had been influenced by friends who encouraged him to join them at Ramgarh in Rajasthan. He had not much liked the place, telling me it had been too hot and the water had a terrible salty taste. Yet it was not long before he departed once more for Kerala, again encouraged by friends. Conditions were a factor but the constant in the lives of migrants from the city was the presence of friends who were already in the destination or with whom migrants travelled. The idea of migrating to a place where one would know nobody was perceived as pushing at the boundaries of the imaginable. In part, this was pragmatic; concerns of exploitation were intensified when migration became associated with isolation. However, there were other, more emotive issues present. The sociality and intimacy of the gullies and the friendships into which young men invested so much time formed a social realm that was itself mobile-a familiar world that could travel with the migrant from place to place. 
Tight bonds and male sociality acted to create emotive and material particularities in the ways woodworkers engaged with migration. For the men and boys of Saharanpur, imagining the future was very much a collective act. Plans were laid and aspirations expressed. However, this was often a group pursuit as young men whiled away the time together, during or between work, in day-dreaming of business plans or of making trips out of the city for either recreation or work. Once hatched, such plans could be rapidly enacted with little sense of upheaval or rupture. However, as quickly as they were established, so they could also be abandoned. A late train, bad weather, the return of an old friend, or just a change of heart could result in cancellation and even the return of only recently purchased tickets. Just as minds may often change and plans be cancelled, so migration itself was often engaged in with a similar degree of ease and ambivalence.

The post-Eid trip was not the first time I followed Faisal. Prior to Eid, I had joined him in Hyderabad, where he was working with another group of friends. The workshop was run by three brothers from Saharanpur whose father had come to the city in 1983 . He had gradually built a business, using contacts in Saharanpur to bring stock and recruit labour. After 30 years, he returned to Saharanpur, saying that 'it is where my heart is', leaving his adult sons to run the business. Success stories like these are by no means universal, yet such tales act to reinforce the hope that, through the gamble of migration, economic and social mobility may be achieved. As Faisal reflects:

I can reach a higher position but it takes time. It may not be possible. Money is necessary. I can do it in the future but now I am not ready. It takes 1 lakh rupees to start. I want to make my own business in the woodcarving industry. Otherwise my plan is to set up a business where there is less investment but also good earnings. ${ }^{67}$

The dream of 'making it' played an important part in shaping the imaginations of migrants. Yet there were other, more emotive factors at play. Musharraf was the senior and most flamboyant member of the group. Tall and handsome, he had spent most of his adult life migrating partly to escape family, in particular his domineering and occasionally violent father, and partly to engage in pursuits not allowed at home. This included drinking alcohol. Musharraf was keen to show me pictures of Goa and regaled me with stories of drunken antics and Western 'girlfriends'. Musharraf played to a crowd for whom such tales

${ }^{67}$ Mohamad Faisal, 2011. 
cemented his status, but also cultivated the imaginaries of younger members of the group who were clearly impressed with his tales. Despite his worldliness, and like others in the group, Musharraf always migrated with others or to places where contacts were already working. Whilst economic gain played a part, he was also concerned with the idea that migration only becomes worthwhile in the company of others and fends off akalapan (loneliness).

Conditions in Hyderabad were basic but held forms of comfort. Ten woodworkers and I shared a single room, located at the front of the employer's house, with thin mats covering the concrete floor. Here we ate, socialized, and slept. Next door was a grubby toilet room with just enough space for a bucket shower. Initially we worked long days, often finishing late. However, Ramadan heralded an earlier finish, allowing time for socializing. Whilst the facilities were basic, the atmosphere was intimate and relaxed. The group were close and friendships deep. Banter and jokes were constant but there was also physical warmth and companionship. Musharraf sat cuddling up with Abdul, whom he nicknamed 'gora' (pale/white) due to his complexion, and joked 'he is my best friend, girlfriend and wife'. The intimacy and male sociality that underpinned everyday life in the small workshop very much represented a continuity from the gullies of Saharanpur, albeit with a little less social or familial constraint. This sense of continuity is important, as it creates familiarity and comfort. As an emotive component to the migration experience, it pushes woodworkers to engage with environments that do not represent a step change from the rhythm and feelings involved in working in the gullies. However, as such, this also begins to hint at an experience unlike the kinds of transformative and change-driving accounts of labour migration outlined in the previous section. These are not migrants necessarily experiencing a transformation of subjectivity along cosmopolitan lines. The imaginations of migrants may be shaped by ideas of adventure, self-making, coming of age, and status but, at a more emotive level, there is also the seeking of familiarity, comfort, and safety. As such, the experiences of those migrating from Saharanpur can also act upon the imagination in relatively enclaving ways that run counter to ideals tying migration with normative projects of cosmopolitanism or a reconfigured social imagination.

The conviviality, comradeship, and intimacy that persisted despite occasional arguments were the source of both belonging and comforta familiarity sought by those far from home. However, it also became a part of negotiations and tactics utilized by workshop owners as 
a means of retaining their labour force. The three brothers who ran the workshop regularly spent evenings in the workers' quarters, playing cards and socializing. This was not merely an instrumental act. The brothers had been born and brought up in Hyderabad; however, their father had come from Saharanpur in the late 1980 s and built up the business, relying on his skill and, as the workshop grew, his ability to access networks to bring other craft workers from Saharanpur. Although they had grown up in Hyderabad, the three saw themselves as belonging to their father's city, with the youngest, Shamshad, complaining to me that South Indians were not so nice as those in the North as they 'think only of themselves', while those from Uttar Pradesh feel 'only love'. Shamshad, too, was conscious of the importance of more emotive elements in his community and the working lives of his labour force.

Whilst work on emotion or affect, in terms of labour spaces, has primarily focused on appeals to the 'spirit' or 'heart' of workers through technologies deployed in the formal sector, ${ }^{68}$ Shamshad and his brothers were also aware of the importance of cultivating more emotive aspects of the working environment. As well as containing affection and providing them with periods away from family, the time invested socializing with their workers acted to narrow distinctions of relative affluence and build friendships that intermingled with the employer/employee relationship. The importance given by workers to conditions beyond that defined by the economic or material was not just an emotive sense shared by the brothers, but also an essential part of fostering commitment and loyalty from their labour force. Yet, despite their best efforts, the imaginations of their labour force were not averse to contemplating other places. The period after Eid proved challenging as the owners struggled to retain workers. On a visit some months later, Shamshad complained 'Mazdoori log jesse kabuter, woh ider uderjatei hai. Unko pakarnai bahut mushkil hai' ('Workers are like pigeons; they go here and there. To catch them is very hard'). Many relocations took place not individually, but collectively. The eventual departure of key members of the group led to several others following as a desire to remain with the group, along with more economic considerations, drove a somewhat haphazard pattern of migration within the group.

\footnotetext{
${ }^{68}$ See, for example, D. Rudnyckyj, 'Circulating tears and managing hearts: governing through affect in an Indonesian steel factory', Anthropological Theory, vol. 11 , no. 1, March 201 1, pp. 63-87; A. R. Hochschild, The Managed Heart: Commercialization of Human Feeling, University of California Press, Berkeley, 2012.
} 
Migration, for Saharanpur's craft workers, had a high degree of unpredictability. It was a fundamentally messy and risky business. Jonathon Parry ${ }^{69}$ has drawn similar parallels amongst Indian steelplant workers in Bhilai (Madhya Pradesh). Parry criticizes the notion that migration can be held as a 'strategy'. Instead, he suggests, 'migrants may see themselves less as strategists than as gamblers playing in a high-risk game of chance [this being symbolized in] the often haphazard, spontaneous and opportunistic way in which the decision to migrate is taken' ${ }^{70}$ For Saharanpur's woodworkers, migration was also haphazard. There was unpredictability and failed migrations are commonplace. My old friend Rizwan, for example, made a trip to Jodphur at the same time as Faisal and his friends were preparing to head to Udaipur. During Eid, news had come from returnees that work and pay were good there. However, the news had spread to others as well and, following Eid, the area was flooded by woodworkers arriving from Saharanpur, leading to a shift from labour shortage to surplus-an occurrence that Rizwan ascribed to kismet (fate) rather than failure. The extent of the networks available to workers from the city meant that migration was often not imagined as a gamble to the degree described by Parry. For Bhilai's steel-plant workers, migration had become bound up in a rupturing experience tied in with a decline of the state steel industry. However, for those travelling out from Saharanpur, the process was accepted and normalized with relative ease.

The ease with which migration was imagined, engaged in, and re-imagined while still in process ensured that the decision to abandon one destination in favour of another was easily undertaken. If the gamble was not paying off, then there was never a sense that upping sticks and heading to another site (with or without a return home between) was anything other than normal. The familiarity of mobility enabled easy onward migration and provided a route out of situations that may be seen as either undesirable or as having served their purpose. In this context, mobility provided a tool through with which migrants could negotiate their position with employers who were only too conscious of their workers' willingness to abandon them. The relative ease with which a new location could be imagined

${ }^{69}$ J. P. Parry, 'Nehru's dream and the village "waiting room": long-distance labour migrants to a central Indian steel town', Contributions to Indian Sociology, vol. 37, no. 1-2, February 2003, pp. $217-49$.

${ }^{70}$ Ibid., p. 220. 
and travelled to suggests a degree of potentiality. Migration, then, can provide space for the expression of agency and the opportunity to improve working conditions.

However, whilst individual and collective projections were a driver of change ${ }^{71}$ the reality of the next destination was often little different. Small factors like the taste of water or the wrong kind of work might result in upping sticks and heading on, but the benefits that made a destination satisfactory were equally incremental. A later trip with Faisal and others who had been in Hyderabad to the town of Kamareddy saw little actual change. Again, we shared a small room and worked on a similar piece rate for long hours. There was time for a quick visit to the gym each morning but, with the wedding season underway, we often worked until midnight. For Faisal, the primary benefit was kharch (cost). The small town contained fewer temptations and food was cheaper. With many of the woodworkers whom I travelled with from Saharanpur, the story was often one of big dreams but a reality of small gains.

Continuity, then, is not only about attending to aspects that make migration relatively easy, but also about understanding the limitations of change in both imagined and material futures. For Faisal and his friends, the work in Kamareddy again contained the same familiarity and comfort embodied in male sociality and intimacy. This eased the transition from one place to another. It also stymied the potential to imagine more dramatic forms of personal and collective transformation. However, my purpose in utilizing a highly descriptive account of internal migration is not just to provide a sense of the everyday, but also to begin exploring the ways in which internal migration shapes the imaginations of those who then go on to engage in international migration. Many of those in the labour camps of the Gulf had a previous history of migration within more local contexts. These histories matter. They shape the expectations and experiences of migrants as they imagine and engage in travel further afield. Overlaps between internal and international migration have been addressed elsewhere through the development of schematic models that attempt to account for geopolitical scale, the unstable nature of borders, and the increased complexities of migrants' journeys. ${ }^{72}$

${ }^{71}$ Gaonkar, 'Toward new imaginaries'.

${ }^{72}$ R. King and R. Skeldon, "“Mind the gap!": integrating approaches to internal and international migration', Journal of Ethnic and Migration Studies, vol. 36, no. 10, December 2010, pp. 1619-46. 
Others have attended to a more subjective position by illustrating how the haphazard nature of migrant networks makes them highly fluid and creates a terrain in which a particular set of connections based on, for example, kin or village (or, as is more common in Saharanpur, friendship and neighbourhood) easily links and overlaps with others. ${ }^{73}$ As Parry ${ }^{74}$ points out, the destinations this opens 'include ones outside India, making it possible for people to imagine a golden future abroad and impossible for us to treat national and international migration separately'. ${ }^{75}$ In the following sections, however, I add to Parry's contribution by exploring not only how internal migration shapes further possibilities, but also how histories of past domestic migration continue to influence the imaginations of those in the Gulf and to shape the ways in which labour camps, work sites, and social worlds are experienced. As with the previous parts of this article, I am focused not only on degrees of change and transformation among migrants, but also on continuities that are part of both imagined and material aspects of migration to the region. In the following, I begin by attending to the history of Gulf migration and the ways in which older forms of connections shape the imaginations of migrants and the materiality of migration itself.

\section{Gulf migration: the imagination in historical perspective}

Saharanpur has seen a rapid burgeoning of migration to the Gulf in the past 20 years or so. With many making the trip and bringing back stories, both migrants and potential migrants are aware of the precarity and riskiness of migration to the region. There are many relative successes (the absence of such would quickly stymie the imaginations of others) but there are also examples of failure and loss. Fear, or the 'nightmare', is as much a part of the consciousness of potential migrants as is the 'dream'. The 'nightmare', in the context of the Gulf, is one not just of financial loss, but also of isolation, entrapment, and akalapan (loneliness), which become intensified as a concern in a context where the ability to up sticks and leave an employer is curtailed. These concerns echo the materiality of Gulf migration-a materiality that is constructed in part through distance,

\footnotetext{
${ }^{73}$ Parry, 'Nehru's dream'.

${ }^{74}$ Ibid.

${ }^{75}$ Ibid., p. 2 20, emphasis added.
} 
but also through both new and older forms of regulation. The kafala system (which restricts workers' period of stay, requires local sponsors, and excludes the possibility of citizenship) is itself constructed in the context of older cultural practice and regulatory histories. Created to regulate pearling dhow (boat) crews who were seen as morally questionable, it was only later formalized to control migrant labour in the 'post-oil' era. ${ }^{76}$ Indeed, state regulation is a primary factor in creating distinctions in experiences of internal and international migration, particularly by curtailing migrant workers' ability to change employers. In a scene where 'flexibility is often achieved by capital through casualization and by labour through its physical movement', ${ }^{77}$ legislative structures act to encourage the former and curtail the latter.

This begins to hint at the importance, when contextualizing a historical narrative of migration and imagination, not to limit the scope to 'India' alone. Work identifying the presence of a 'methodological nationalism' challenges entrenched views of 'state' or 'nation' as a natural category. ${ }^{78}$ Likewise, notions of 'area', such as South Asia, have been contested as often being themselves imagined or created within scholarly and colonial contexts. ${ }^{79}$ Historical and geographical explorations reveal more fluid landscapes that push us to "imagine other spatial configurations, such as "crosscutting" areas, the worldwide honeycomb of borderlands, or the process geographies of transnational flows' ${ }^{80}$ International migration, then, cannot be thought of as only a contemporary phenomenon brought about through 'globalization', but instead plays out over far longer periods ${ }^{81}$ and is constructed through 'intensified flows along already well-trodden, established, well narrated and imagined pathways'. ${ }^{82}$

${ }^{76}$ A. N. Longva, Walls Built on Sand: Migration, Exclusion and Society in Kuwait, Westview, Boulder, 1997.

${ }^{77}$ B. Harriss-White, India Working: Essays on Society and Economy, Cambridge University Press, Cambridge, 2003, p. 24.

${ }^{78}$ U. Beck, Cosmopolitan Vision, Polity, Cambridge, 2006; A. Wimmer and N. G. Schiller, 'Methodological nationalism and the study of migration', European Journal of Sociology, vol. 43, no. 02, August 2002, pp. 21 7-40.

${ }^{79}$ W. Van Schendel, 'Geographies of knowing, geographies of ignorance: jumping scale in Southeast Asia', Environment and Planning D, vol. 20, no. 6, December 2002, pp. $647-68$.

${ }^{80}$ Ibid., p. 647 .

${ }^{81}$ E. Ho, The Graves of Tarim: Genealogy and Mobility across the Indian, University of California Press, Berkeley, CA, 2006.

${ }^{82}$ T. B. Hansen, 'Migration, religion and post-imperial formations', Global Networks, vol. 14 , no. 3 , July 2014 , p. 754 , emphasis added. 
The imaginations of migrants are not shaped only in the present era of time-space compression and increasing connectedness, but within broader historical contexts that offer 'ways' or 'paths' beyond contemporary infrastructure and are embedded in circuit of trade, religious networks, or colonial configurations.

The trajectories of early journeys to the Gulf from Saharanpur interlocked not just with networks of internal migration established by migrants from the city, but also with older pathways embedded in colonial and pre-colonial trade and connection. As Thomas Blom Hansen points out: 'When the need for labour of all kinds grew dramatically in the Gulf from the 1970s onwards, the colonial networks and pathways were already well established and Mumbai was the first place to which Arab employers went in search of labour and other services. ${ }^{93}$

I first met Habib through a mutual friend. Having recently returned from a lifetime of trips to the Middle East, he was resettling in his native city as now, being in his late fifties, he was considered too old to obtain work visas for the Gulf. It was with one of these interactions that Habib Aqueel's long history of Gulf migration, now drawn to a close, had begun. Having migrated to Mumbai, he was approached by a Qatari business man who offered him work. After an awkward meeting at the Taj Continental and a brief negotiation over wages, he accepted, telling me:

I was fearful as I thought they could hurt me. I was fearful as I would be alone there and that is not good but I could see that people who came back from the Gulf had many good clothes and money in their pocket. It is human weakness that we also want a life like that so I went.

Whilst Habib Aqueel was not the first from Saharanpur to travel to the Gulf, he was among the earliest. Moreover, it was his initial internal migration to the nodal city of Mumbai and his meeting with a Qatari businessman, who was himself intertwined in older circuits of trade across the Indian Ocean, that led to his first trip. The blurring of lines between internal and international migration are clear, with nodal spaces, such as Mumbai, creating sites of overlap.

Habib, as with Rizwan prior to his first trip to Mumbai, had been influenced by his own imaginings based on the style and exoticism brought by migrants returning to Mumbai from the Gulf. However, images of migrants differ greatly, depending on the perspective from

${ }^{83}$ Ibid., p. 283 . 
which others view them and upon which part of a region, that is far from homogenous, they have visited, as a wholesaler in Purani Mandi reflects:

If they go to Saudi, they come back with high moral and religious values but if they go to other parts of the Gulf they return with low values. Either way they don't want to work in this industry as they consider the wages to be too low and look instead to go back outside. They don't invest in this industry either, but just buy property and try to go abroad again.

There is a degree of reality in these imaginings, even if they may be somewhat amplified by those creating them. Over his lifetime, Habib had visited several Gulf states and was clear regarding the distinctions in his experience:

Dubai is a free port so it is not strict but Saudi is very strict. Qatar is also not so strict but not as easy as Dubai. It is in the middle. In Saudi, many things are banned. When it is Namaaz time then a big van comes and the owner gives us instruction to go for Namaaz. It is the company who send the van to make sure all the workers go. There is no alcohol in Saudi, life is simple and straight and we cannot do any free thing. Some people who go to Dubai want to drink alcohol and do bad things. ${ }^{84}$

It was Saudi that proved the most common destination among those from Saharanpur. This may be tied up with economic demand. However, as the location of Mecca and Medina, it had further appeal. Although most migrants were unlikely to be able to complete Hajj, there was usually the chance for Umrah. ${ }^{85}$ Shahid, another friend, expressed his desire to go not just for work, but also to visit the holy sites. Similarly, Rizwan had Saudi in mind for his eldest son, Abdul. Whilst he was in two minds about the benefits of working overseas, he saw Saudi as the preferred location, as it would allow Abdul to learn more about Islam and ensure respectability.

In Saharanpur, numerous informal flows have shaped both imaginaries and networks of migration. Migration (whether imagined or real) is not shaped through globalization alone, but also through historical formations embedded in cultural, religious, and political histories that may not conform to clearly bounded categories and that contain their own forms of power, inequality, and exploitation.

\footnotetext{
${ }^{84}$ Habib, 2011.

${ }^{85}$ Visiting of the holy sites of Mecca that, unlike Hajj, can be performed at any time of year. The Umrah is seen as increasing one's religious standing and closeness to Allah. However, it does not hold the weight of Hajj.
} 
Dale Eickelman and James Piscatori ${ }^{86}$ have emphasized the role of Islamic and other religious networks in shaping contemporary flows and as reshaped through newer forms of migration. As they suggest, 'contemporary labour migration ... has facilitated changes in religious institutions and practices as important as those inspired by earlier generations of elite Muslim intellectuals in the Middle East and Indian sub-continent'. ${ }^{87}$ Whilst labour migration is a contemporary phenomenon, ongoing religious connectivity has been present in Saharanpur, not least through the nearby Madrassa at Deoband. ${ }^{88}$ Latterly, this has been supplemented by visiting Tabligh Jamaats (religious tours) ${ }^{89}$ that add a sense of Islamic cosmopolitanism to the city and provide the imagination with a sense of being part of something bigger than neighbourhood, community, or nation state.

During the first year of fieldwork in the city, except for those occasions spent going elsewhere with migrants, I worked daily in the shop of Mohammad Islam. Islam was a brass over-layer, and became my ustad (teacher) in the trade. Unlike many in the gullies, he had never engaged in labour migration, in part due to health issues that limited his ability to travel. However, he had been through a transformative process via his involvement in the Tabligh Jamaat. His first 40-day Jamaat had led him to adopt more pious practices; wearing his trousers short and beard long, he now positioned himself as observant and respectable. It also gave him a sense of connection to other places and people that were somewhat suppressed by his health issues. He often told me of the Jamaatis he had met from various countries; however, of these, it was those from Saudi who impressed him most:

Before some years ago there was only one or two jamaats in India but now it has changed and in lakhs the jamaats come. There is no place in the world where the jamaat cannot go. Some time ago one jamaat came from Saudi in

${ }^{86}$ D. F. Eickelman and J. P. Piscatori, 'Introduction', in Eickelman and Piscatori, Muslim Travellers.

${ }^{87}$ Ibid., p. 5 .

${ }^{88}$ B. Metcalf, 'The madrasa at Deoband: a model for religious education in modern India', Modern Asian Studies, vol. 1 2, no. o1, February 1978, pp. 111 1-34.

${ }^{89}$ The Tabligh Jamaat allows individuals to participate per economic means. The movement disseminates religious authority from the Madrassas, to lay participants. Jamaats regularly set out from masjids in Saharanpur. These groups constituted labourers, farmers, and artisans. At the other end of the scale, multinational Jamaats come from across the world, including Africa, Europe, America, and the Gulf. 
Khathakheri. All were Arab people and were very handsome and beautiful people ... If I am in Saudi, then I cannot do any bad thing. ${ }^{90}$

Whilst partly embedded in historical and religious imaginaries, Islam's sentiment also illustrates how ongoing circulations continue to shape the imaginations of those in the city. However, images conjured in the minds of migrants and potential migrants are by no means fixed, but play out through affective circuits of movement, religiosity, objects, styles, and media that blur what the Gulf is and how it is seen. ${ }^{91}$ The person of the Gulf migrant may be imagined by others in multiple and simultaneous ways, at once embodying the experienced adventurer, the pious Muslim, the abandoner of duty, or the person of questionable morals. A young man returning from Dubai and boasting of drinking and women may be seen as having adopted loose morals by some in the mohallas and sway the imagination away from the benefits of such a destination, as was the case for Rizwan with regard to his son, Abdul. For others, however, it is the very same tales that may further the returnees' status in the imaginations of friends and neighbours and inspire a desire for emulation.

However, such tales could be mediated in various ways. The images conjured by returnees for those thinking of making the trip and for others were not told in a context free from the politics, concerns, and social norms of the mohallas. One afternoon, across the gully from Islam's workshop, I sat chatting to Ifran, who had recently returned from Saudi. He was not full of tales of adventure and success, but instead painted a bleaker picture, agreeing that the (Saudi) Maliks treated the workers 'kutte kee tarah' (like dogs). As we chatted, we were joined by the Iman of the neighbouring Madrassa. I had known the Iman for some time and, whilst stern, he was an affable character of rotund frame in his late fifties. Notable, however, was the change in Ifran's tone. At the very moment of the Iman's arrival, he switched from his scathing account of conditions in Saudi to a far more idealized tenor that gave emphasis to the respectful religiosity they were taught and the purity of Islam in the kingdom.

Nuances in the stories told and imaginations forged reflected, in the varied accounts of returnees, the ways in which tales may be revised, depending upon the cultural context, the company one is in, or the

\footnotetext{
${ }^{90}$ Mohamad Islam, 2011.

${ }^{91}$ Radhakrishnan, 'The Gulf in the imagination'.
} 
life stage of the migrant. ${ }^{92}$ Tales of exploitation and opportunity, sacrifice and glory, confinement and adventure, ambivalence and ambiguity all feature. Younger men, in particular, tended toward positive interpretations. Experiences were often couched in ways that built status among piers. In Purani Mandi, a group of young men made ornamental banister pillars. I stopped at their shop occasionally for tea and a chat. They were always bantering and often included me. They introduced me to Usman Malik. He had recently returned from Kuwait and was full of bluster and boasts as he ensured that his friends and others in neighbouring shops were aware of his worldly experiences. As a tanga (horse-drawn taxi) passed, he mocked the driver for the backwardness of his vehicle. His friends laughed and applauded as he revelled in his new image. Later, however, a nearby craftsman told me 'of course it is all lies, he [Usman] has only been working as a servant to some big malik'. Older returnees, such as Habib, were somewhat more circumspect:

It is not a beneficial system for us, but it is not so harmful either. I spent my life away. I spent 18 years outside and I earned a lot of money but I am like a stranger in my own country now. My goodwill is finished now. No one can recognise me. My circulation of work is finished too and I am like a new person so I have to start from step one. Yes, I spent my life out of the country but I am happy as my family spent their life in comfort .... When we are outside then we are always under pressure as the family always calls asking for this thing or that thing. ${ }^{93}$

Migration can be seen as a process aimed at building social networks beyond the confines of kin and neighbourhood. ${ }^{94}$ However, in the very act of committing to these new connections, migrants may in fact lose access to the original networks that they set out with the intention of broadening. Habib's early migrations had been undertaken at a time when a Gulf returnee held undoubted status as an exceptional or even heroic character in the imaginations of others. However, with the increasing normalization of migration to the Gulf, Habib had seen a steady decline in status that paralleled the gradual erosion of his 'circulation' in the mohallas. Towards the end of fieldwork, I dropped in to say a final goodbye to Habib. His son, Faisal, answered the door

\footnotetext{
${ }^{92}$ For a seminal account attending to these areas in story-telling, see K. Gardner, Age, Narrative and Migration: The Life Course and Life Histories of Bengali Elders in London, Berg Publishers, London, 2002.

${ }^{93}$ Habib, 2011 (edited and adapted from interview transcript).

${ }^{94}$ Monsutti, 'Migration'.
} 
and explained that Habib was away on Jamaat. Habib's earnings had funded a religious education for his three sons and they had encouraged him to undertake the new journey. His son continued: 'We have told him that now it is time to leave this useless work in the Gulf and to turn to the important work of Islam.'

Faisal's words were indicative of his own religious positionality, but also reflected broader societal shifts around the ways in which migration to the Gulf was viewed and imagined. In some sending areas, such as Kerala, prolific Gulf migration and the presence of powerful affective circuits have led to a shift in terms of the national consciousness of migrants, with many no longer considering the Gulf a foreign land. ${ }^{95}$ As with Syed Ali's ${ }^{96}$ identification of a 'culture of migration' in Hyderabad, Saharanpur had also seen the increasing normalization (and therefore de-exceptionalization) of Gulf migration. However, with the more recent emergence of Gulf migration in Uttar Pradesh and other areas of North India, this normalization is still very much in formation. There are also important distinctions associated with the materiality and types of labour engaged in by migrants from the area that create distinctions in imaginings and experiences of the Gulf. Unlike Percot's explorations of national consciousness in Kerala, returning Gulf migrants do not tend toward a vision that blurs national boundaries. Whilst much migration from Uttar Pradesh to the Gulf is circular, for labour migrants, the kafala system and the segregation of the labour camps from cities and cosmopolitan centres mean that there is little chance to establish roots. As with circular migrants elsewhere, this leaves little possibility of assimilation or incorporation. ${ }^{97}$ This is also further emphasized by an emerging ethnically tied class structure within the Gulf. With Keralans moving into health, education, and skilled middleclass jobs, ${ }^{98}$ experiences are increasingly segregated from semi-skilled and unskilled labour roles occupied by North Indians, Pakistanis,

${ }^{95}$ M. Percot, 'Indian nurses in the Gulf: two generations of female migration', South Asia Research, vol. 26, no. 1, 2006, pp. 41-62.

${ }_{96} \mathrm{Ali}$, "Go west young man"'.

${ }^{97}$ P. Levitt, J. DeWind, and S. Vertovec, 'International perspectives on transnational migration: an introduction', International Migration Review, vol. 37, no. 3, September 2003, pp. $5^{6} 5^{-75}$.

${ }^{98}$ B. Khadria, 'India: skilled migration to developed countries, labour migration to the Gulf', in Migration and Development: Perspectives from the South, S. Castles and R. Delgado Wise (eds), International Organization for Migration, Geneva, 2008, pp. 79112 ; B. A. Prakash, 'Gulf migration and its economic impact: the Kerela experience', Economic and Political Weekly, Vol. 33, no. 5o, December 1998, pp. 3209-13. 
Nepalis, and Bangladeshis. In other words, the ability to imagine oneself as being 'transnational' ${ }^{99}$ is impacted upon by class and ethnic identities shaped through the forms of engagement one experiences in the destination labour market. It also stymies opportunity for the development of a more cosmopolitan imagination. Whilst bringing together labourers from various backgrounds, by design, the labour camps provide a relatively segregating and enclaving experience.

However, this enclavement is not necessarily seen in negative terms by those contemplating migrations to the Gulf. As with internal migration (even more so given the risks involved and the inability to change employer or return), the primary concern in the minds of potential migrants, who were used to travelling and working with others in the city or elsewhere in India, was a fear of isolation. In some ways, this represented the nightmare scenario, as not only could isolation make you more vulnerable to exploitation, but it could also change the imagined experience of life overseas from one bound up in the camaraderie, male sociality, and intimacy, familiar to internal migrants, into a period dominated by akēlappan (loneliness). Journeys with others were seen as passing easily, but a lone journey was to be avoided. Thus, Rizwan reflected on his concerns about using an agent to find Abdul work:

You know the agent is expensive and we do not have money for this. I do not think it matters for the work as the agent can also arrange good jobs but it is better for Abdul to go to some factory where there is one person already as otherwise he could be alone in some place.

This was not mere supposition. Mohammad Abdul ran a small shop, having returned after several trips. He explained that both he and his eldest son went for work in Saudi. Their work was arranged through an agent and was to be in a furniture factory. Whilst this was the case for Abdul, the owner decided to utilize his son as a gardener in a distant farmhouse. Abdul explained how his son often cried to him about having no one with him. After three months, Abdul went to visit his son and, upon seeing his condition, pleaded with the owner to allow him to relocate. Eventually it was agreed they would get another gardener and allow his son to move. His son has since returned to the Gulf, but this time made arrangements of an informal manner with people whom the family knew through their mohalla. This draws the thread of this article back towards reflection on more affective aspects

\footnotetext{
${ }^{99}$ S. Vertovec, Transnationalism, Routledge, Abingdon, 2009.
} 
of migration. As with the previous section on internal migration, it also requires a shift in focus away from the narratives of potential migrants, migrants, returnees, and others in Saharanpur towards a more experiential account that shares in the everyday experience of migrant life in the Gulf. It is the attention to a more emotive engagement with migration that provides a contribution beyond much of the existing material on migration and the imagination. Therefore, the following section turns to everyday life in the dormitory blocks in the labour camps of Sharjah and Abu Dhabi.

\section{Following arrival: the dormitories}

Finding Gulfam was not easy as I struggled with the building Gulf heat in May of 2012. My newly acquired UAE sim-card was playing up and our calls were often cut off. I knew he was somewhere in the sprawling sub-metropolis of Mussafah, the vast industrial area on the outskirts of Abu Dhabi. Having made the trip from Shahjah, a neighbouring emirate, I could only think to join the line dominated by South Asians at the central bus station. Sure enough, when the bus did pull in and the scramble for seats began, I was relieved to see its board displaying 'Mussafah Worker's City'. Still unable to reach Gulfam, I stayed on the bus through a maze of construction yards full of heavy equipment and roughly hewn dormitory blocks until the end of the line. Obtaining numbers of migrant workers in the area is difficult; however, the Gulf News describes 'Al Mussafah [as an] area where an estimated 12,000 workers often share cramped rooms containing up to 20 beds' ${ }^{100}$ Recently, it has been earmarked for development, which may see the relocation of migrant labour elsewhere. ${ }^{101}$ Mussafah is strategically located across a creek and is geographically very much segregated from Abu Dhabi proper. The area itself consists of a mix of yards and storage for construction materials and equipment interspersed by numerous dormitory blocks for construction workers. The coalescence of workers' accommodation and construction materials in the same

${ }^{100}$ GulfNews, 'Cramped in a room with poor wages and diseases to boot', April 2006, http://gulfnews.com/news/gulf/uae/employment/cramped-in-a-room-with-poor-wages -and-diseases-to-boot-1.232227, [accessed 25 January 2018].

${ }^{101}$ M. Bajić-Brković and M. Milaković, 'Planning and designing urban places in response to climate and local culture: a case study of Mussafah District in Abu Dhabi', Spatium, no. 25, 2011 , pp. 14-22. 
location is, perhaps, symbolic of the status given to these men within the city state's social stratification.

Finally, after several crackly conversations and help from a Chennaiborn taxi driver, I met Gulfam and we headed for the dormitory block. I had never met Gulfam prior to arriving in Mussafah, having been introduced to him by phone through a mutual friend in Saharanpur. At that time, he was in Sharjah working for a company fitting interiors in new buildings. Just before my arrival, he was transferred to Abu Dhabi. Gulfam was older than I expected. Although I imagined a younger man during our telephone conversations, he turned out to be around 40, with greying hair and a full frame. Gulfam was a foreman for a group doing interior fitting, mostly carpentry, and had 15 men in his charge. However, for him, this was a step down. In Saharanpur, he had owned a furniture business. Whilst it was not particularly large, he described how he used to be his own master. Financial problems, however, led to a decline in his business and eventually he was forced to shut down. It was this that drove him to look for work in the Gulf as a way of acquiring sufficient capital to restart.

We made our way, along with the company driver, to the dormitory block. Situated between a couple of shops and a construction storage yard, the block consisted of a steel gate that opened onto a courtyard, with doors to the rooms on three sides. Gulfam's room was the first on the right. I tried to lay my bedding on the floor but Gulfam insisted that I take his bunk. The room was shared with five others. Gulfam, however, told me that, in some rooms, there were two men sharing a bed. Despite this, conditions were slightly better than those I had experienced while migrating with workers in India. Each room had a rickety $\mathrm{AC}$ unit and the bunks had mattresses. There was a kitchen, containing numerous stoves, that became crowded, hot, and full of the smell of a variety of South Asian cooking during meal times as the burners were fired up. The men made their own food, the duty of which was often shared on a per-room basis. Rooms naturally divided into national groupings brought together by common language and shared taste preferences. Yet, in many ways, it was a cosmopolitan space. Bangladeshis, Pakistanis, and Indians joined each other in the courtyard to play football, chat, and share jokes. Behind the dorm rooms, there was a substantial toilet and shower block, which was a world apart from the small facility in Hyderabad or Kamareddy. The dormitory block was not provided by the Jordanian-owned company for whom all the residents worked, but was leased from a company specializing in dormitory accommodation. 
My initial impression was that many facilities were provided but, when we began to pack up to return to Sharjah, it became clear this was not so. Apart from the bunks, AC units, and toilets, everything was loaded onto a lorry including mattresses, cookers, gas cylinders, a couple of fridges, and even carpet tiles from the floor. Gulfam explained that all these items had been bought by the workers themselves. Some, such as cookers and cylinders, had been purchased collectively within rooms, whilst others, such as mattresses, had been bought to provide a little comfort. Whilst there were some distinctions, the material arrangements and conditions felt, in the context of my previous migrations with friends in India, familiar. Friday still provided a day of respite and an opportunity to go roaming in the city or just laze around in the dorm. Whilst I could access the camp, the worksite was out of bounds to me. The hours were long and overtime often demanded by the employer. However, the rhythm of the day was not greatly different from that in Hyderabad or Kamareddy. The evenings were spent in the dorm room or in the communal courtyard onto which our door opened. Gulfam shared the small room with five other men. Of these, four were also from Saharanpur and, with one exception, had arranged work at the site through informal channels that were largely an extension of migration networks within the domestic context. Just as Faisal could call others in various corners of India, so potential Gulf migrants were more and more able to make links to work through friends, neighbours, and others who were already in or had returned from the Gulf. There were material advantages to preferring a more informal passage, as it enabled migrants to cut out costly agents. Faisal also hailed from Saharanpur but had organized work through an agent, eventually paying out about Rs 9o,ooo in advance to secure a three-year contract.

The fifth resident was Junaid, from a village near Lucknow. He was the most experienced of them all, having spent 15 years abroad, returning home only to obtain new contracts. For Junaid, as with Musharraf in Hyderabad, life had become defined by migration and he said he preferred this to life at home. The others joked that this was because his wife was 'buhuut mota' (very fat), jesting that 'Junaid Bhai pasia nehee mil suktai hai kyoki uskee beebi sub khatee hai' ('brother Junaid cannot make any money as his wife eats it all'). As with the worksites in India, there was more than the mere materiality of conditions that provided a degree of continuity far from home. The banter, conviviality, and intimacy of life in the camps very much reflected that of migrant destinations in India. All the occupants of the room 
had engaged in internal migration prior to setting off for the Gulf and these experiences provided a primary reference point for their expectations of migration beyond the domestic context. Whilst the Gulf may be imagined in a variety of ways, the experience of being there was as much bound up in degrees of familiarity as it was in difference. The men of this dorm room shared common language, tastes in food, and interests. Evenings were spent engaging in the same kinds of jovial intimacy and occasional disagreements present in domestic destinations. The conditions often described by media outlets and others as cramped and dirty may indeed be such, but there are material familiarities for those residing in them and reasons beyond structural concerns why workers themselves often accept the arrangements they find themselves in.

Yet, in seeking comfort and familiarity, the everyday life of workers in the Gulf shapes an imagination that contrasts to ideals of a vanguard or cosmopolitan migrant. Continuity can create forms of enclavement rather than necessarily opening transformative horizons. This is partly structural, as spatial segregation is a prominent part of the urban landscape, yet there was also a degree to which continuity was actively sought out. The courtyard of the camp was a space that offered potential for something more. Yet, whilst there was conviviality in the yard, there remained a degree of ethnic segregation among the workers and more intimate time was always shared with those of a more familiar background.

My time in the dormitories of Abu Dhabi was limited. Unlike in India, I was unable to obtain permission to work. By day, I was mostly alone, as the workers headed out to the sites where they were fitting internal décor. They showed me photos of stylish apartments they had worked on. The rooms contained fittings and fixtures that would not be out of place in any fancy catalogue. The lobbies were grand, with tall ceilings and airy spaces. They also showed snaps from the public beach in Dubai. They were particularly keen on a photo of Abdul, one of those with whom we shared a room, in which the background scene contained a Western woman in a bikini. Indeed, the photo was staged to surreptitiously capture her image. The moment took me back to Hyderabad and a trip to a shopping mall with Faisal and Usman. They were regular visitors to the mall, which is attached to an IMAX cinema, but, unlike the hordes of middle-class Indian shoppers, the ways in which they could experience it were limited. We looked in the windows of the shops, rode the escalators, and sat in McDonalds for a few minutes without ordering anything. As with the skyscrapers on 
which Gulfam and the other men worked and the foreign women they illicitly photographed, much of what has been conceptualized within the context of cosmopolitanism and modernity could be seen but not touched.

Routes to the Gulf vary. They may involve connections that bring internal migrants into contact with spaces and people who provide a link to further networks of recruitment. They may involve agents or brokers. Increasingly, as Gulf migration becomes more common, they involve friends or relatives who work, or have previously worked, in Saudi, Qatar, or Dubai. The ways potential migrants imagine or judge destinations vary, as do the views of non-migrants regarding returnees. For those finding new religiosity in Saudi or elsewhere, this may be seen as a strengthening of their moral fabric or be met with derision, mockery, or resentment. Likewise, those who return from locations seen as filled with vice may be viewed with suspicion regarding their ethical and religious standards or with excitement regarding the very same attributes. Migration, then, is imagined not only in advance, but also in retrospect. The resulting retrospective image may be equally affected by the social groups with whom a migrant associates at home ${ }^{102}$ as with the realities of the destination. Distorted images, perhaps created for economic ends, concerns of religiosity, or to bolster one's status and prestige, are themselves active in reshaping the imaginaries of other potential migrants. This ongoing process revolving between the real and the imagined, the domestic and the international, and the origin and destination lies at the core of the cyclic production of migrants' imaginations.

\section{Conclusion}

This article has utilized an experiential ethnographic account to better understand everyday realities of migrants within India and in the Gulf. Whilst embedded in description, the stories of migrants from Saharanpur reveal the significance of considering the imagination in driving decision-making processes. This takes us beyond simplistic,

\footnotetext{
102 These groups in themselves may vary and thus migrants may present various images to others according to the relations and expectations of the members of one group or another.
} 
and much critiqued, models of economic 'push and pull'. 103 It problematizes the distinction between the 'economic' and 'noneconomic', with the imaginaries of migrants ranging across this dichotomy. It illustrates the blurring of the internal and external, in terms of both the material world and the imagination, as well as national and international forms of migration. In so doing, the article illuminates the importance of considering links between internal and external migration in shaping imaginaries and subjective experiences. Significantly, however, attending the imagination as a realm of ethnographic enquiry has drawn out more emotive considerations that, whilst not necessarily articulated by migrants themselves, form a highly significant part of the fabric of migrant life.

Through attending to the fluid space between the 'imagined' and the 'material', the article has illustrated the problems of overstating the rupturing or change-driving potential of migration upon the lives of individuals, communities, or hierarchies. Instead, migration was experienced within a sense of relative continuity. As Ghassan Hage points out, it 'is a mistake to think that if people move across national borders, such a movement will necessarily be the most significant thing in their lives'. ${ }^{104}$ Indeed, life in the Gulf holds much that is familiar to those who have previously migrated within India. The atmosphere of the camps, the shared living spaces and intense social scene, the hours of work, and the rhythm of life are not so exceptional, but are easily slipped into and accepted. The major exception, of course, is the restriction of mobility in the Gulf, which is, for internal migrants, the primary bargaining chip. Andrew Smith ${ }^{105}$ has been even sharper in critiquing the potentiality of the imagination amongst migrants. Citing work with middle-class Nigerian migrants in the United Kingdom, he points out that the oft-ignored facilitator in the relative success of their migrations is their class position. Smith argues that middle-class migrants assign much of their success to their own efforts and ascribe this success with a degree of inevitability. He points out that, for many lower-class migrants, the reality does not live up to aspirations or dreams conjured up in the imagination. The imagination, Smith argues, has a social quality: 'The way in which an

${ }^{103}$ J. P. Harris and M. P. Todaro, 'Migration, unemployment and development: a two-sector analysis', American Economic Review, vol. 6o, no. 1, 1970, pp. $126-42$.

${ }^{104} \mathrm{G}$. Hage, 'A not so multi-sited ethnography of a not so imagined community', Anthropological Theory, vol. 5, no. 4, December 2005, p. 496.

${ }^{105}$ Smith, "If I have no money". 
individual can conceive of themselves and what they might imagine as their possible future are acts which are themselves socially and historically determinate. Our imaginations are not placeless: Even the most utopian dream is dreamed contextually. ${ }^{106}$

Whilst this article has emphasized forms of continuity, it has also attended to change and transformation: the shift to adulthood that migration may accelerate; the role of the returnee bringing newfound styles, stories, and status in cultivating the imaginations of others; and the degrees to which migrant life may ease familial or social restrictions and open possibilities for new experiences to be imagined and enacted. However, it is critical to weigh our enthusiasm for the potentiality of migration as an agent of social change-a facet of migration often ascribed from the perspective of academia, with the realities and imaginaries of migrants themselves. This is not to dismiss all potentiality. The account I have provided in this article covers a single ethnoscape. Ethnographic material gathered elsewhere illustrates that degrees of change and transformation are present within migration, including in some accounts from the Gulf. Writing on migration from Kerala to the Gulf, Michelle Buckly, ${ }^{107}$ for example, points out that there have been strikes amongst construction workers in the Gulf, which took place despite spatial configurations, an ethnically divided labour market, and regulatory frames aimed at controlling the labour force. The imagination always contains potentiality. However, migration is by no means an automatic catalyst. Just as we give focus to the forms of change bound up in migration, so attending to continuity in the actual experiences of migrants pushes us to consider why transformative processes may not be initiated. Migration does hold the possibility to open new imaginative horizons, but it is by no means a normative project in its own right. Finally, the ethnographic material presented in this article has contributed to an important body of work which reminds us that migration is not only an economic outcome or singular event, but also a biographical and contextual process.

${ }^{106}$ Ibid., p. 54 .

${ }^{107}$ M. Buckley, 'From Kerala to Dubai and back again: construction migrants and the global economic crisis', Geoforum, vol. 43, no. 2, March 201 2, pp. 250-9. 